\title{
Pengaruh Mata Kuliah Kewirausahaan dan Keterampilan Berwirausaha Terhadap Motivasi Berwirausaha Mahasiswa
}

\author{
Kiki Ismanti ${ }^{1}$, Sigit Indra Prianto ${ }^{2}$ \\ Universitas Indraprasta PGRI
}

\begin{tabular}{|c|c|}
\hline ARTICLE INFO & ABSTRACT \\
\hline $\begin{array}{l}\text { Article History: } \\
\text { Received: } 10 \text { September } 2021 \\
\text { Revised: } 10 \text { November } 2021 \\
\text { Accepted: } 11 \text { November } 2021 \\
\text { Published: } 30 \text { Desember } 2021\end{array}$ & $\begin{array}{l}\text { The purpose of this study is to find out how much influence the existence of } \\
\text { entrepreneurship courses on student motivation in running a business. The study } \\
\text { was conducted using correlational survey methods. The study was conducted in } \\
\text { kampung Gedong area of East Jakarta. with location selection in multistage } \\
\text { cluster sampling. Based on this, the sample was taken from the students who }\end{array}$ \\
\hline $\begin{array}{l}\text { Keywords: } \\
\text { Kewirausahaan; } \\
\text { Ketrampilan Mahasiswa; } \\
\text { Motivasi. }\end{array}$ & $\begin{array}{l}\text { Indraprasta University PGRI Jakarta amounting to } 144 \text { students. Entrepreneurship } \\
\text { courses and entrepreneurship skills together affect entrepreneurship motivation. } \\
\text { This is evidenced by the results of hypothesis testing through multiple regression } \\
\text { analysis obtained that the value of Sig }=0.000 \text { and Fhi num }=16,589 \text {, while Ftabel } \\
=3.06 \text {. Because sig values }<0.05 \text { and Fhitung }>\text { Ftabel which means the } \\
\text { regression is significant. The implication of this research is that it needs to be } \\
\text { increased motivation for students and the need for mentoring to students who are } \\
\text { just starting their business, so that their business can grow. }\end{array}$ \\
\hline
\end{tabular}

Tujuan dari penelitian ini adalah untuk mengetahui seberapa besar pengaruh adanya mata kuliah kewirausahaan terhadap motivasi mahasiswa dalam menjalankan bisnis. Penelitian ini dilakukan dengan menggunakan metode survei korelasional. Penelitian dilakukan di wilayah Kampung Gedong Jakarta Timur. dengan pemilihan lokasi secara multistage cluster sampling. Berdasarkan hal tersebut maka sampel diambil dari para mahasiswa pengampu mata kuliah kewirausahaan program studi Teknik Informatika Universitas Indraprasta PGRI Jakarta berjumlah 144 mahasiswa. Mata kuliah kewirausahaan dan keterampilan berwirausaha secara bersama-sama berpengaruh terhadap motivasi berwirausaha. Hal ini dibuktikan oleh hasil pengujian hipotesis melalui analisis regresi ganda diperoleh bahwa nilai $\boldsymbol{S i g}=0.000$ dan $\boldsymbol{F}_{\text {hitung }}=16,589$, sedangkan $\boldsymbol{F}_{\text {tabel }}=3,06$. Karena nilai $\boldsymbol{S i g}<0,05$ dan $\boldsymbol{F}_{\text {hitung }}>\mathbf{F}_{\text {tabel }}$ yang berarti regresi tersebut signifikan. Implikasi dari penelitian ini adalah perlu ditingkatkan lagi motivasi terhadap mahasiswa serta perlu adanya pendampingan kepada mahasiswa yang baru memulai usahanya, agar usahanya bisa berkembang.

Corresponding Author:

Kiki Ismanti

Email: kiki161983@gmail.com

How to Cite: Ismanti, K., Prianto, S.I. (2021).Pengaruh mata kuliah kewirausahaan dan keterampilan berwirausaha terhadap motivasi berwirausaha mahasiswa. Sosio e-Kons, 13 (03), 168-174

\section{PENDAHULUAN}

Dalam Undang Undang Sisdiknas No. 20 Tahun 2003, n.d., Pendidikan adalah usaha sadar dan terencana untuk mewujudkan suasana belajar dan proses pembelajaran agar peserta didik secara aktif mengembangkan potensi dirinya untuk memiliki kekuatan spiritual keagamaan, pengendalian diri, kepribadian, kecerdasan, akhlak mulia, serta keterampilan yang diperlukan dirinya dan masyarakat. 
Pendidikan merupakan hal yang tidak dapat dipisahkan dari kehidupan masyarakat. Pendidikan merupakan kegiatan yang sangat kompleks. Hampir seluruh aspek kehidupan manusia berhubungan dengan proses pendidikan. Hal ini sesuai dengan pernyataan (Redja Mudyaharjo, n.d.), pendidikan merupakan usaha sadar yang dilakukan oleh keluarga, masyarakat, dan pemerintah, melalui kegiatan bimbingan, pengajaran dan latihan yang berlangsung di sekolah dan di luar sekolah sepanjang hayat, untuk mempersiapkan peserta didik agar dapat memainkan peranan dalam berbagai lingkungan hidup secara tepat di masa yang akan datang. Pendidikan nantinya akan berguna bagi masyarakat dikemudian hari.

Sugihartono Dkk, (2007), Pendidikan adalah suatu usaha yang dilakukan secara sadar untuk mengubah tingkah laku manusia baik secara individu maupun kelompok untuk mendewasakan manusia melalui upaya pengajaran dan pelatihan sehingga mempunyai kemampuan untuk bertanggung jawab terhadap segala perbuatannya.

Dari pendapat para pakar diatas dapat disimpulkan bahwa pendidikan adalah suatu kebutuhan bagi semua orang, karena inti dari pendidikan adalah proses untuk mendewasakan manusia atau mengentaskan kebodohan dan mampu berfikir secara cerdas. Kemudian mereka akan mampu berkerja dan bersaing dengan dunia luar. Ketika berbicara dengan pendidikan, mengarah pada pendidikan matapelajaran atau matakuliah kewirausahaan hakikatnya ada yang perlu kita perhatikan dan kita bombing, yaitu para mahasiswa.

Mempersiapkan para mahasiswa dalam memulai bisnis baru melalui integrasi pengalaman, keterampilan, dan pengetahuan penting untuk mengembangkan dan memperluas sebuah bisnis. Generasi muda menjadi target utama program pendidikan kewirausahaan. Berbagai upaya dilakukan untuk menumbuhkan jiwa kewirausahaaan terutama dengan merubah mindset para generasi muda yang selama ini hanya berminat sebagai pencari kerja (job seeker) apabila kelak menyelesaikan kuliah mereka. Dalam hal ini, para mahasiswa di perguruan tinggi diharuskan mendapat pendidikan kewirausahaan secara mendetail dan menyeluruh. Pendidikan kewirausahaan akan mendorong para mahasiswa agar memulai mengenali dan membuka usaha. Melihat fenomena yang terjadi, angkatan kerja terdidik lulusan perguruan tinggi jumlahnya semakin meningkat dalam setiap tahun. Para mahasiswa rata-rata belum merencanakan pekerjaan setelah lulus dari perguruan tinggi. Pemerintah telah mencanangkan agar pendidikan kewirausahaan diterapkan di perguruan tinggi sebagai upaya menciptakan wirausahawirausaha muda berstatus sarjana yang berkompeten untuk ikut membantu pemerintah dalam mengurangi angka pengangguran. Pendidikan kewirausahaan diharapkan dapat memberikan bekal wawasan dan keahlian berwirausaha kepada mahasiswa saat lulus nanti.

(Mahendra et al., 2017) penelitian mengungkapkan bahwa kewirausahaan niat secara tidak langsung dipengaruhi oleh pendidikan kewirausahaan, artinya motivasi berwirausaha siswa dan sikap adalah dua variabel mediasi yang penting

Menurut(Kasmir, 2006) kewirausahaan adalah suatu kemampuan menciptakan kegiatan usaha. Kemampuan menciptakan dan memerlukan adanya kreativitas dan inovasi dari yang sudah ada sebelumnya. Kemampuan berwirausaha yang kreatif dan inovatif dapat dijadikan dasar, kiat, dan sumber daya untuk mencari peluang menuju sukses (Suryana, 2006). Peluang sukses di masa depan dapat diraih apabila seorang wirausaha benar-benar memanfaatkan peluang dengan baik dan mempunyai disiplin diri.

Sedangkan menurut Zimmerer dalam (Suryana, 2006)Kewirausahaan merupakan penerapan kreativitas dan inovasi untuk memecahkan masalah dan memanfaatkan peluang yang dihadapi. Kreativitas diartikan sebagai kemampuan mengembangkan ide-ide dan menemukan cara-cara baru dalam memecahkan masalah, sedangkan inovasi diartikan sebagai kemampuan menerapkan kreativitas untuk memecahkan masalah dan peluang untuk meningkatkan kekayaan hidup. Kekuatan pemikiran wirausaha harus dinyatakan dengan pengetahuan akan berbagai pendekatan bisnis, tidak hanya pikiran yang tajam tetapi seorang wirausaha juga memiliki pengetahuan tentang keuangan dan masalah sosial. Pengetahuan ini dapat diperoleh melalui instansi terkait maupun sekolah-sekolah dan perguruan tinggi. 
Berdasarkan pengamatan dan pengalaman, hanya sebagian kecil mahasiswa saja yang tetap melanjutkan bisnis. Motivasi awal mahasiswa dalam melaksanakan wirausaha dikarenakan ingin mendapatkan nilai dan memenuhi syarat kuliah, sehingga motivasi berwirausaha masih rendah. Sebagian mahasiswa juga masih takut terjun di bidang wirausaha karena merasa belum mempunyai keterampilan dalam mengelola bisnis dan dibayangi resiko ketidakberhasilan ataupun rugi. Apabila mahasiswa mengetahui manfaat berwirausaha, yaitu mereka dapat menciptakan lapangan pekerjaan bagi orang lain dan menghasilkan pendapatan yang besar dari seorang karyawan.

Motivasi merupakan salah satu faktor keberhasilan wirausaha dalam menyelesaikan tugasnya. Semakin besar motivasi maka semakin besar kesuksesan yang dicapai. Faktor-faktor pendorong disebut juga faktor penyebab kepuasan. Adanya kepuasan akan menambah semangat untuk melaksanakan aktivitas(H.A. Rusdiana, 2014)

Dari uraian diatas penelitian ini mempunyai Tujuan adalah mata untuk mengetahui seberapa besar pengaruh adanya mata kuliah kewirausahaan terhadap motivasi mahasiswa dalam menjalankan bisnis.

\section{METODE}

Penelitian dilakukan di wilayah Kampung Gedong Jakarta Timur. dengan pemilihan lokasi secara multistage cluster sampling. Penelitian ini dilakukan dengan menggunakan metode survei korelasional. Sedangkan analisis yang digunakan untuk menguji kebenaran hipotesis dilakukan dengan analisis regresi linier sederhana.

Populasi dari penelitian ini adalah mahasiswa Teknik Informatika semester 6 yang mengampu mata kuliah kewirausahaan baik regular pagi, sore maupun ekstensi kurang lebih berjumlah 1.440 mahasiswa. Oleh karena itu, yang menjadi target dalam penelitian ini adalah para mahasiswa pengampu mata kuliah kewirausahaan program studi Teknik Informatika universitas Indraprasta PGRI Jakarta.

Hal ini berdasarkan pendapat Suharsimi Arikunto, (2006), mengemukakan bahwa, "untuk memenuhi persyaratan penelitian apabila subjek kurang dari 100, maka lebih baik diambil semua, sehingga penelitiannya merupakan penelitian populasi. Selanjutnya jika subjeknya besar dapat diambil antara 10\% - 15\% atau 20\% - 25\% atau lebih. Berdasarkan hal tersebut maka sampel diambil dari para mahasiswa pengampu mata kuliah kewirausahaan program studi Teknik Informatika Universitas Indraprasta PGRI Jakarta berjumlah 144 mahasiswa.

\section{HASIL DAN PEMBAHASAN}

\section{Hasil}

Deskripsi data Keterampilan Berwirausaha

Tabel 1

Uji Normalitas Galat

One-Sample Kolmogorov-Smirnov Test

\begin{tabular}{ccc}
\hline & & $\begin{array}{c}\text { Unstandardized } \\
\text { Residual }\end{array}$ \\
\hline \multirow{2}{*}{ Normal Parameters $\mathrm{a}, \mathrm{b}$} & Mean & 144 \\
& Std. Deviation & .0000000 \\
Most Extreme Differences & Absolute & .049 \\
& Positive & .049 \\
\cline { 2 - 3 } & Negative & -.045
\end{tabular}




\begin{tabular}{lc}
$\qquad \quad$ Test Statistic & .049 \\
\multicolumn{1}{c}{ Asymp. Sig. (2-tailed) } & $.200 \mathrm{c}, \mathrm{d}$ \\
\hline a. Test distribution is Normal. & \\
b. Calculated from data. & \\
c. Lilliefors Significance Correction. & \\
d. This is a lower bound of the true significance. &
\end{tabular}

Dari tabel 1 di atas menunjukkan bahwa uji hipotesis yang menyatakan distribusi residual pada analisis regresi ini mengikuti distribusi normal. Hal ini ditunjukkan dengan nilai $Z=0,049$ dan Sig. $=$ $0,200>0,05$. Hal ini berarti asumsi atau persyaratan analisis regresi terpenuhi.

\section{Uji Linearitas}

Uji lineritas dilakukan untuk menentukan teknik dalam analisis regresi apakah variabel bebas (X1) dan variabel terikat $(Y)$ terbentuk linear. Uji linearitas ini menggunakan perhitungan SPSS 20.Hasil uji linearitas regresi sederhana, perhitungan SPSS 20 sebagai berikut:

Tabel 2

Hasil Pengujian Linearitas Regresi Variabel $Y$ atas $X_{1}$

ANOVA Table

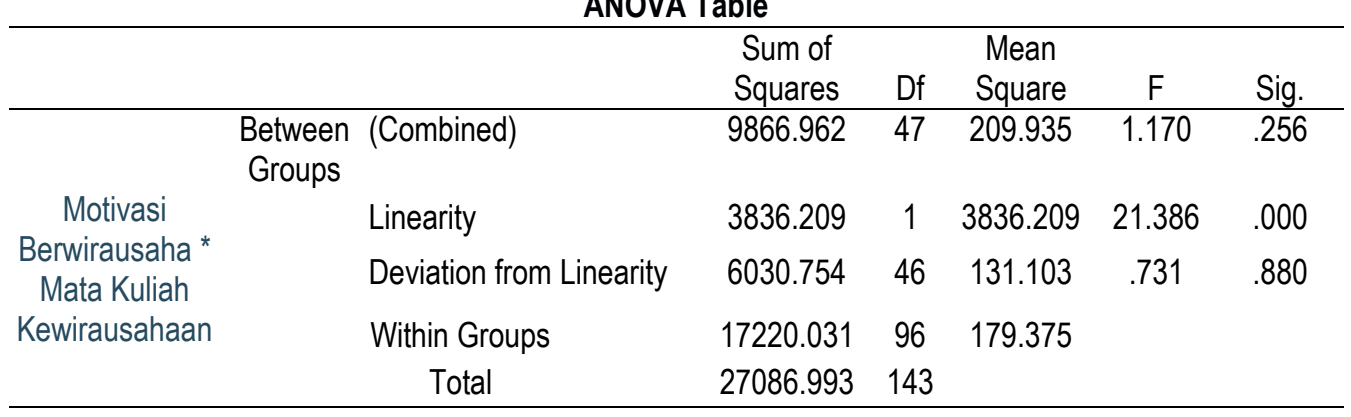

Berdasarkan hasil perhiungan di atas diperoleh hasil perhitungan Deviation from Linearity dengan $\mathrm{Fo}_{0}=0,731$ dan Sig. $=0,880>0,05$. Hal ini memiliki pengertian bahwa variabel pengaruh mata kuliah kewirausahaan atas motivasi berwirausaha mempunyai hubungan yang linear.

Tabel 3

Hasil Pengujian Linearitas Regresi Variabel $\mathrm{Y}$ atas $\mathrm{X}_{2}$

ANOVA Table

\begin{tabular}{|c|c|c|c|c|c|c|c|}
\hline & & & Sum of Squares & $\mathrm{df}$ & Mean Square & $F$ & Sig. \\
\hline \multirow{6}{*}{$\begin{array}{c}\text { Motivasi } \\
\text { Berwirausaha * } \\
\text { Keterampilan } \\
\text { Berwirausaha }\end{array}$} & Between & (Combined) & 10065.644 & 54 & 186.401 & .975 & .534 \\
\hline & Groups & Linearity & 1338.836 & 1 & 1338.836 & 7.000 & .010 \\
\hline & & Deviation from & 8726.808 & 53 & 164.657 & .861 & .720 \\
\hline & & Linearity & & & & & \\
\hline & Wit & Groups & 17021.349 & 89 & 191.251 & & \\
\hline & & otal & 27086.993 & 143 & & & \\
\hline
\end{tabular}

Berdasarkan hasil perhiungan di atas diperoleh hasil perhitungan Deviation from Linearity dengan $\mathrm{Fo}=0,861$ dan Sig. $=0,720>0,05$. Hal ini memiliki pengertian bahwa variabel keterampilan berwirausaha atas motivasi berwirausaha mempunyai hubungan yang linear.

\section{Pengujian Hipotesis}

Hasil perhitungan dan pengujian bisa dilihat pada tabel di bawah ini: 
Tabel 4

Hasil Perhitungan Koefisien Korelasi Pengaruh Variabel $X_{1}$ dan $X_{2}$ terhadap Variabel $Y$

Model Summary

\begin{tabular}{ccccc}
\hline Model & $\mathrm{R}$ & $\mathrm{R}$ Square & Adjusted R Square & $\begin{array}{c}\text { Std. Error of the } \\
\text { Estimate }\end{array}$ \\
\hline 1 & $.436^{\mathrm{a}}$ & .190 & .179 & 12.471 \\
\hline
\end{tabular}

a. Predictors: (Constant), Keterampilan Berwirausaha, Mata Kuliah Kewirausahaan

Tabel 5

Rekapitulasi Hasil Perhitungan Pengujian Signifikasi Koefisien Regresi Pengaruh Variabel X1 dan X2terhadap Variabel Y Coefficientsa

\begin{tabular}{clccccc}
\hline & & Unstandardized Coefficients & \multicolumn{2}{c}{$\begin{array}{c}\text { Standardized } \\
\text { Coefficients }\end{array}$} \\
Model & B & Std. Error & Beta & $\mathrm{t}$ & Sig. \\
\hline 1 & (Constant) & 42.018 & 8.936 & & 4.702 & .000 \\
& Mata Kuliah Kewirausahaan & .385 & .078 & .376 & 4.957 & .000 \\
& Keterampilan Berwirausaha & .177 & .061 & .221 & 2.917 & .004 \\
\hline
\end{tabular}

a. Dependent Variable: Motivasi Berwirausaha

Tabel 6

Rekapitulasi Hasil Perhitungan Persamaan Garis Regresi Pengaruh Variabel $\mathrm{X}_{1}$ dan $\mathrm{X}_{2}$ terhadap Variabel $\mathrm{Y}$ ANOVAa

\begin{tabular}{ccccccc}
\hline & Model & Sum of Squares & Df & Mean Square & $\mathrm{F}$ & Sig. \\
\hline 1 & Regression & 5159.513 & 2 & 2579.757 & 16.589 & $.000 \mathrm{~b}$ \\
& Residual & 21927.480 & 141 & 155.514 & & \\
& Total & 27086.993 & 143 & & & \\
\hline
\end{tabular}

a. Dependent Variable: Motivasi Berwirausaha

b. Predictors: (Constant), Keterampilan Berwirausaha, Mata Kuliah Kewirausahaan

\section{Pembahasan}

Pengaruh Mata Kuliah Kewirausahaan dan Keterampilan Berwirausaha. Secara Bersama-sama Terhadap Motivasi Berwirausaha. Untuk membuktikan hipotesis tersebut, digunakan hasil perhitungan yang dilakukan dengan bantuan komputer melalui program aplikasi SPSS 21. Hasil perhitungan dan pembahasanannya adalah sebagai berikut :

Dari Tabel 4. di atas terlihat bahwa koefisien korelasi ganda pengaruh variabel bebas mata kuliah kewirausahaan dan keterampilan berwirausaha secara bersama-sama terhadap motivasi berwirausaha adalah sebesar 0,436.

Sedangkan koefisien determinasinya adalah sebesar 19\% menunjukkan bahwa besarnya kontribusi mata kuliah kewirausahaan dan keterampilan berwirausaha secara bersama-sama terhadap motivasi berwirausaha adalah sebesar 19\%, sisanya (81\%) karena pengaruh faktor lain.

Untuk pengujian hipotesis melalui analisis regresi diperoleh hasil perhitungan terlihat pada Tabel 5. dan Tabel 6 Dari Tabel 5. diperoleh persamaan garis regresi yang merepresentasikan pengaruh variabel $X_{1}$ dan $X_{2}$ terdahap variabel $Y$, yaitu $\widehat{Y}=42,018+0,385 X_{1}+0,177 X_{2}$.

Pengujian signifikansi garis regresi tersebut adalah dengan memperhatikan hasil perhitungan yang ada pada Tabel 5. Menurut ketentuan yang ada, kriteria signifikansi regresi tersebut adalah "jika Sig $<0.05$ maka $\mathrm{H}_{0}$ ditolak" atau "jika $\mathbf{F}_{\text {hitung }}>\mathbf{F}_{\text {tabel }}$ maka $\mathrm{H}_{0}$ ditolak", yang berarti bahwa koefisien regresi tersebut signifikan, dengan kata lain terdapat pengaruh yang signifikan variabel bebas $X_{1}$ dan $X_{2}$ terhadap variabel terikat $Y$. Nilai Sig adalah bilangan yang tertera pada kolom Sig dalam Tabel 5 Nilai $\mathbf{F}_{\text {hitung }}$ adalah bilangan yang tertera pada kolom $\mathbf{F}$ dalam Tabel 5 . Sedangkan nilai $\mathbf{F}_{\text {tabel }}$ adalah nilai tabel distribusi $\mathbf{F}$ untuk taraf nyata $5 \%$ dengan derajat pembilang $(\mathrm{k})=2$ dan derajat penyebut $(\mathrm{n}-\mathrm{k}-$ 1) $=143$ dimana $n$ adalah banyaknya responden, dan $k$ adalah banyaknya variabel bebas. 
Dari Tabel 6, terlihat bahwa nilai Sig $=0.000$ dan $\boldsymbol{F}_{\text {hitung }}=16,589$, sedangkan $\boldsymbol{F}_{\text {tabel }}=3,06$. Karena nilai Sig $<0,05$ dan $\boldsymbol{F}_{\text {hitung }}>\mathbf{F}_{\text {tabel }}$ maka $\mathrm{H}_{0}$ ditolak yang berarti bahwa koefisien regresi tersebut signifikan. Dengan kata lain bahwa terdapat pengaruh yang signifikan variabel bebas mata kuliah kewirausahaan $\left(X_{1}\right)$ dan keterampilan berwirausaha $\left(X_{2}\right)$ secara bersama-sama terhadap motivasi berwirausaha $(\mathrm{Y})$.

Dari hasil pengujian korelasi maupun pengujian regresi tersebut maka bisa disimpulkan bahwa terdapat pengaruh yang signifikan variabel mata kuliah kewirausahaan dan keterampilan berwirausaha secara bersama-sama terhadap motivasi berwirausaha

\section{Pengaruh mata kuliah kewirausahaan terhadap motivasi berwirausaha}

Untuk membuktikan hipotesis tersebut adalah dengan memperhatikan nilai/bilangan yang tertera pada kolom $\mathbf{t}$ atau kolom Sig untuk baris mata kuliah kewirausahaan (Variabel $\mathrm{X}_{1}$ ) pada Tabel 5.8. Menurut ketentuan yang ada, kriteria signifikansi regresi tersebut adalah "jika $t_{\text {nitung }}>\mathbf{t}_{\text {tabel }}$ maka $\mathrm{H}_{0}$ ditolak" atau "jika Sig < 0,05 maka $\mathrm{H}_{0}$ ditolak", yang berarti bahwa terdapat pengaruh yang signifikan variabel bebas $X_{1}$ terhadap variabel terikat $Y$. Nilai Sig adalah bilangan yang tertera pada kolom Sig untuk baris mata kuliah kewirausahaan (Variabel $\mathrm{X}_{1}$ ) dalam Tabel 5.8. Nilai $t_{\text {hitung }}$ adalah bilangan yang tertera pada kolom $\mathbf{t}$ untuk baris mata kuliah kewirausahaan (Variabel $\mathrm{X}_{1}$ ) dalam Tabel 5 Sedangkan nilai $\boldsymbol{t}_{\text {tabel }}$ adalah nilai tabel distribusi $\mathbf{t}$ untuk taraf nyata $5 \%$ dengan derajat kepercayaan $(\mathrm{df}=\mathrm{n}-2)=142$ dimana $\mathrm{n}$ adalah banyaknya responden.

Dari Tabel 5.8, terlihat bahwa nilai $\mathbf{S i g}=0.000$ dan $\mathbf{t}_{\text {hitung }}=4,957$, sedangkan $\mathbf{t}_{\text {tabel }}=1,655$. Karena nilai $\mathrm{Sig}<0,05$ dan $\mathrm{t}_{\text {hitung }}>\mathrm{t}_{\text {tabel }}$ maka $\mathrm{H}_{0}$ ditolak yang berarti terdapat pengaruh yang signifikan variabel bebas $X_{1}$ (mata kuliah kewirausahaan) terhadap variabel terikat $Y$ (motivasi berwirausaha).

Dari hasil pengujian korelasi, pengujian regresi maupun dengan melihat model garis tersebut maka bisa disimpulkan bahwa terdapat pengaruh yang signifikan variabel bebas $\mathrm{X}_{1}$ (mata kuliah kewirausahaan) terhadap variabel terikat $Y$ (motivasi berwirausaha).

\section{Pengaruh Keterampilan Berwirausaha terhadap Motivasi Berwirausaha}

Untuk membuktikan hipotesis tersebut adalah dengan memperhatikan nilai/bilangan yang tertera pada kolom $\mathbf{t}$ atau kolom Sig untuk baris keterampilan berwirausaha (Varia-bel $\mathrm{X}_{2}$ ) pada Tabel 5 Menurut ketentuan yang ada, kriteria signifikansi regresi tersebut adalah "jika $\mathbf{t}_{\text {hitung }}>\mathbf{t}_{\text {tabel }}$ maka $\mathrm{H}_{0}$ ditolak" atau "jika Sig < 0,05 maka $\mathrm{H}_{0}$ ditolak", yang berarti bahwa terdapat pengaruh yang signifikan variabel bebas $X_{2}$ terhadap variabel terikat $Y$. Nilai Sig adalah bilangan yang tertera pada kolom Sig untuk baris keterampilan berwirausaha (Variabel $X_{2}$ ) dalam Tabel 5.8. Nilai $t_{\text {hitung }}$ adalah bilangan yang tertera pada kolom $\mathbf{t}$ untuk baris keterampilan berwirausaha (Variabel $\mathrm{X}_{2}$ ) dalam Tabel 5.8. Sedangkan nilai $t_{\text {tabel }}$ adalah nilai tabel distribusi $t$ untuk taraf nyata $5 \%$ dengan derajat kepercayaan $(\mathrm{df}=\mathrm{n}-2)=142$ dimana $\mathrm{n}$ adalah banyaknya responden.

Dari Tabel 5, terlihat bahwa nilai Sig $=0.000$ dan $\mathbf{t}_{\text {hitung }}=2,917$, sedangkan $\mathbf{t}_{\text {tabel }}=1,655$. Karena nilai Sig $\left\langle 0,05\right.$ dan $\mathbf{t}_{\text {hitung }}>\mathbf{t}_{\text {tabel }}$ maka $\mathrm{H}_{0}$ ditolak yang berarti terdapat pengaruh yang signifikan variabel bebas $\mathrm{X}_{2}$ (keterampilan berwirausaha) terhadap variabel terikat $\mathrm{Y}$ (motivasi berwirausaha).

Dari hasil pengujian korelasi, pengujian regresi maupun dengan melihat model garis tersebut maka bisa disimpulkan bahwa terdapat pengaruh yang signifikan variabel bebas (keterampilan berwirausaha) terhadap variabel terikat. Dari informasi kuantitatif tersebut maka peneliti berkesimpulan bahwa terdapat pengaruh variabel bebas mata kuliah kewirausahaan) dan (keterampilan berwirausaha) secara bersama-sama terhadap variabel terikat $Y$ (motivasi berwirausaha).

Di dalam penelitian terdahulu (Dewi, 2013), hasil penelitian ini adalah pengalaman pendidikan kewirausahaan di sekolah, keluarga dan masyarakat serta keterampilan kejuruan secara parsial maupun bersama-sama berpengaruh positif terhadap motivasi berwirausaha siswa Tata Busana SMK di Kabupaten Klaten. Persamaan dengan penelitian ini adalah menggunakan analisis deskriptif kuantitatif 
menggunakan teknik analisis regresi sederhana dalam mengetahui masing-masing variabel, variabel dependen menggunakan variabel motivasi berwirausaha.

Yunita Widyaning Asti, (2014), Penelitian ini merupakan penelitian populasi dengan responden mahasiswa pendidikan ekonomi angkatan 2011 yang berjumlah 88 mahasiswa. Teknik pengambilan data menggunakan kuesioner dan dokumentasi. Metode analisis data yang digunakan adalah regresi linier sederhana. Hasil penelitian ini menunjukkan bahwa pendidikan kewirausahaan berpengaruh positif dan signifikan terhadap motivasi berwirausaha.

\section{SIMPULAN DAN SARAN}

Dengan adanya sinergi motivasi dari dosen kewirusahaan, Mata kuliah kewirausahaan dan keterampilan berwirausaha secara bersama-sama berpengaruh terhadap motivasi berwirausaha ( $Y$ ).

Implikasi dari penelitian ini adalah perlu ditingkatkan lagi motivasi terhadap mahasiswa serta perlu adanya pendampingan kepada mahasiswa yang baru memulai usahanya, agar usahanya bisa berkembang.

Sebaiknya mahasiswa diarahkan agar mampu mencari pemodal atau penanam saham, dengan cara memberikan pelatihan pembuatan bisnis plan, sehingga usaha yang sudah dijalankan atau belum dijalankan mendapatkan dukungan modal dari berbagai arah, missal seperti Program Kreatifitas Mahasiswa progam yang di jalankah oleh pemerintah melalui kampus.

\section{REFERENCES/DAFTAR PUSTAKA}

Dewi, A. V. (2013). Pengaruh Pengalaman Pendidikan Kewirausahaan dan Keterampilan Kejuruan terhadap Motivasi Berwirausaha Siswa. Journal Pendidikan, vol 3(no 2).

H.A. Rusdiana. (2014). Kewirausahaan Teori Dan PraktikBandung: Cv Pustaka Setia. Cv Pustaka Setia. Kasmir. (2006). Kewirausahaan. Pt Rajagrafindo Persada.

Mahendra, A. M., Djatmika, E. T., \& Hermawan, A. (2017). The Effect of Entrepreneurship Education on Entrepreneurial Intention Mediated by Motivation and Attitude among Management Students, State University of Malang, Indonesia. International Education Studies, 10(9), 61. https://doi.org/10.5539/ies.v10n9p61

Redja Mudyaharjo. (n.d.). Pengantar Pendidikan. Pt Rajagrafindo Persada.

Sugihartono Dkk. (2007). Psikologi Pendidikan. Uny Press.

Suharsimi Arikunto. (2006). Proses Penelitian: Suatu Proses Pendekatan Praktik (ke 6). Rineka Cipta. Suryana. (2006). Kewirausahaan Pedoman Praktis, Kiat Dan Proses Menuju Sukses. Salemba Empat. UU SISDIKNAS no. 20 tahun 2003. (n.d.).

Yunita Widyaning Asti. (2014). Pengaruh pendidikan kewirausahaan terhadap motivasi berwirausaha dan keterampilan berwirausaha mahasiswa pendidikan ekonomi universitas negeri yogyakarta. Journal E-Resources. http://eprints.uny.ac.id/id/eprint/16075 